\title{
Evaluation of Media Policies in Order To Protect Local Film Community
}

\author{
Lintang Ratri Rahmiaji ${ }^{* 1}$, Muh. Bayu Widagdo ${ }^{1}$ \\ ${ }^{1}$ Department of Comunication, Universitas Diponegoro, Semarang, Indonesia
}

\begin{abstract}
Based on Film Law (2008), the Government is obliged to promote the national film industry. But in reality, independent film industry in the local district needs more attention. The research purpose is to examine the role of local government in developing the film community and alternative screening spaces. This study uses a qualitative approach with explorative analysis, to map power relations between government, independent arts institutions, and independent film community. As results, there is a knowledge gap about the role, obligation and duties of local government, between central government, local government, local art council, indies film communities and society, in efforts to encourage the growing of film communities. Local Art Council doesn't cover all of the film communities and tends to giving attention only for their members. All stakeholders in the development of indie films are not synergy which then becomes counterproductive to the existence of indies movie community. To address this gap, a discussion forum is needed to find the best solution to resolve the issue of independent filmmaking in the region.
\end{abstract}

Keywords: Peran, Pemerintah Daerah, Komunitas Film, Film Indie, Industri Film

\section{Introduction}

Indonesia has a lot of talented young filmmakers, this is evidenced by the various awards films achieved on the international scene. In the year 2017 recorded eight award-winning international films including "Athirah", won the INALCO Award from des Cinemas d'Asia Vesoul 2017, "The Seen and Unseen" received an award from Asia Pacific Screen Award- Tokyo Filmex International Film Festival for Best Youth The film, "Senyap" was nominated for Best Documentary Feature Oscar 2016, 'Break the Words' of a successful Love's Folly (Love is Folly) Film Festival in Bulgaria (2017), "Battle of Surabaya" came out as Best Animated Film in Milan International Filmmaker Festival 2017, "Turah" was chosen to represent Indonesia for Oscar 2018 Best Foreign Language Film category, there is also a low budget film, "Siti", won Best Scriptwriter at Shanghai International Film Festival and Best Performance at Singapore International Festival 2016, "Marlina, the Killer in Four Rounds" won the NETPAC Jury Award at Five Flavor s Asian Film Festival 2017, best screenplay on the 1st Morocco FIFFS, and award for best film Asian Nest Wave from The QCinema Film Festival, Philippines. This achievement is remarkable considering the national film ups and downs of the early 2000s, hardly any movies worth discussing, except Sherina Adventures. National film industry rally began to rise after the movie "Jelangkung" (2001) and "Ada Apa Dengan Cinta" (2002).

The film is one of the forms of mass media that has since gained public attention. On December 28, 1985 the

\footnotetext{
*Corresponding author: lintangratri84@gmail.com
}

world was stunned by August and Louis Lumiere who appalled Grand Café guests on the Boulevard de Capucines by presenting a silent film "Worker Leaving the Lumiere Factory". The term indie film, or independent, was spearheaded by academician Institut Kesenian Jakarta as a symbol of resistance to the major film industry, as well as for national films not to die. Some film artists insist on refusing to move to a booming 2000s era soap opera such as Christine Hakim who has chosen to be involved in the movie "Daun di Atas Bantal" and "Pasir Berbisik." Before producing "Jelangkung" which hits in theaters, Rizal Mantovani produces film "Kuldesak" as well as pioneering indie film in Indonesia, after which comes the movie "Bintang Jatuh" which strengthens director Rudi Sudjarwo in the realm of the indie movie stream.

In introduction to Beginner Films Training in five major cities in 2002 by the Pop Corner Foundation, young filmmakers limited the term indie as a major film contradiction produced for business purposes. Indie films focus more on channeling idealism, then it is usually sponsored independently. In addition, the duration of the aired about 10-25 minutes, voluntary production involvement, and the use of simple tools, this is related to production costs. However, A. Baksin (2002) found the fact that indie films were the forerunners of the strengthening of the national films, the presence of kine clubs in student circles and the emergence of an independent film community was a first step for the provision of human resources in the field of film [1].

Producing a movie requires hard work and sponsorship support, after which it still requires 
appreciation spaces like a work of art. To be a full piece of work, the film moves through educational activities, production, distribution and appreciation. This makes the film must be supported by many parties in its growth and development. In 1976, the Communication Planning and Polities seminar in Hawaii concluded that communication planning and mass media communication policy (where one of the films) can be managed as a commodity, which must be considered elements of production and distribution, and therefore should be supported by government infrastructure, as well as soft infrastructure. Infrastructure hard one of them in the form of network, frequency availability. While soft infrastructure includes government policies, relationships among social institutions, the relationship between social institutions with government agencies, socio-cultural situations and others. Referring to the Film Law of 2009, the role of the government is underscored in the definition that the film as a work of art and culture has a strategic role in enhancing the resilience of the nation's culture and the welfare of society, cinema is the responsibility of the government. Even in detail, the local government's duties on the film industry in article 44 and article 55. However, preliminary observations indicate that there is lack of local government support in this case represented by the culture and tourism office of Central Java, in effort to encourage the growth of indies film communities specially for the appreciation and productions of indies film. This study mainly focuses to unravel the power relations that surround the existence of the indies film community. Secondly, this research in order to assess the extent of the role of local government of Semarang city in an effort to encourage the growth of film community and alternative screening spaces.

\section{Methodology}

This research is categorized into qualitative research method [2], using explorative analysis. The subjects of the research are independent filmmakers in Semarang city, the managers of the film community (both those who focus on the making, workshop, and appreciation of indie short film), and activists of alternate screening spaces in Semarang city, and the local government of Semarang city this is the Department of Culture and Tourism and the Arts Council of Semarang.

\section{Discussion}

This research refers to the concept of power from Foucault to show how the distribution of knowledge power then influenced the growth of the Film community in Semarang. The power in Faucault's view is not ownership but a strategy. Therefore the Faucault does not separate knowledge and power. Through knowledge, power practices self-coercion to people without arguing in an objective framework or imposing a standardized standard as scientific or applicable. Remarkably, people usually do not realize beyond that there is actually a practice of arbitrariness that accepted and accepted culture is the dominant or culture of the winner. For Foucault, power is not the property of the ruling class, power is a strategy, in which the unequal relation is between the strong / powerful and the not. Where there is power there arises anti power. Power is not viewed as a negative thing that must be cultivated, power is a thing that can produce (productive) [3].

In an attempt to map the protection and empowerment issues of independent film communities, as well as access to alternative film spaces in Semarang, researchers conducted comprehensive interviews with all stakeholders, such as the government represented by the Department of Culture and Tourism, the Council Semarang Art, Film Community and Alternative Space Screen Manager. Based on interviews with the film community and alternative screening managers whether they know and understand the rights of creative workers in public policy on films, especially on independent films, and how the central and local government's obligations in protecting and supporting the development of independent film, community film managers and alternative screening spaces claim to have no control over the content contained in the law in detail, even those related to independent film. The next thing questioned is how the role of local government in supporting the growth of film community and alternate screening spaces in Semarang City, almost all informants stated that the screening space is very less, and that there is still problem with the limited number of seats, the camera is not feasible and restrictions on the movie being played. As representatives of film community managers who need appreciation, their informants have tried to communicate with the government related to criticism of alternative screening spaces that are considered less proper. However, the negative response provided by Central Java Governor Ganjar Pranowo actually made them more distant with the government, and chose to be self-reliant.

Furthermore, regarding the cooperation with the local government, the informants claimed to have never initiated any cooperation, and or invited to cooperate. However, they feel more comfortable working with the film community than the local government because of bureaucratic matters that are too complicated. Meanwhile, for data collection and filing of indie film in Semarang City, it is considered not yet systematized properly. The hope of alternative space managers to the government is to support the planned programs, one of which is the film festival which is often constrained cost. On the other hand, the film community managers also expect the growth of healthy ecosystems in the growth of independent films, that all parties put themselves optimally in their respective fields, moving in synergy that will eventually support each other in the growth of sound regional cinema.

From the side of the Arts Council of Semarang (DKS), Handry TM, Chairman of DKS period 20162020 felt never distant with the movie community in Semarang. Budget issues become the main obstacle in running art programs. DKS own budget is attached to the Department of Culture and Tourism (Disbudpar), is designed independently and no intervention but how much the budget ceiling and approval must pass 
Disbudpar. This means that no matter how many submissions from DKS there is no increase in the amount of budget to be received, as it has been determined.

Agus Priyo as chairman of the committee of DKS cinema rejects the notion that DKS does not accommodate the existence of the film community in Semarang. One of the programs of DKS is the development of databases, and has been running so far, in the sense that many community film activities are already under way, and many film communities are involved. If anyone does not know the existence of DKS may be missed and DKS open for database updates. Meanwhile, from Disbudpar side, the Head of Department of Masdiana Safitri explained that during this time his side as the representation of the government always be positive and cooperative in supporting the growth of film community in Semarang. Disbudpar has Lawang Sewu Festival which is provided with special booth about Semarang movie, where film producers including independent film can participate to promote Semarang. As a provincial cultural and tourism manager, Masdiana also does not justify that Disbudpar is separated with an independent film community, Masdiana said Histeria often cooperate with Disbudpar. Meanwhile, strengthening the statement of the head of his department, Kasturi, Head of Culture, said there is a fundamental problem faced by local governments related to budgetary assistance to film activities in the region. Kasturi refers to the regulation of "Cultural Affairs Division of Cultural Affairs According to Law NO.23 Year 2014 on Regional Government" issued by Directorate of Regional Government Affairs II of the Directorate General of Regional Autonomy of the Ministry of Home Affairs Year 2015. The rules regulate the authority, responsibility of local government on culture, including the film. Seven sub cultural affairs that are organized include, culture, national film, traditional arts, history, cultural heritage, museums, cultural heritage.

Of the seven cultural sub-branches, the sub-affairs of film and cultural reserves of authority exist only at the central level, while provincial and district governments or municipalities have no authority to regulate them. This is the difficulty of local governments to submit budgets for film activities, in the end film funds can be lowered but linked to creative economic activities. This means that the government can only finance the film activities as long as it supports the growth of regional creative economy, such as film production that promotes Semarang, so cannot be for training or workshops.

If the government looks the other possibility of benefit of financing the film indie activities in various genres, the government can contribute in maintaining and preserving the environment. It is because of some of indie filmmaker manage film as the medium of nature conservation campaign, for instance is Joe Yaggi who works for Bumi Hijau TV and owns Jungle Run Production that focuses on environmental themes. Government necessarily is able to notice this example to leverage their campaign of raising public awareness about environment.
Based on the findings of the field, it can be read that there is a communication problem between institutions concerned in the film industry area. Here it appears that power is not distributed fairly, in the sense that not all film communities or alternative movie screen managers know the work program of the government, have no access to the work program nor on budgeting activities that can support the production and appreciation of independent films. The Arts Council as a community protector also has not conducted a comprehensive data collection, so that the distribution of knowledge is also only around the film community managers who are close to the "power" or even limited to their own members, this is because the arts board leader also has a production house and manage the film community personally. On the other hand, the stigma and negative views of the film community to the bureaucratic-related government have broadened the distance and fostered resistance to cooperation with the government. Another interesting finding is that legally, there are rules that do not allow local governments to budget on film activities in the region, all set at the central level. This is the justification of local government not to prioritize film activities in the region.

\section{Conclusion}

There is a knowledge gap about the role, obligation and duties of local government, between central government, local government, local art council, indies film communities and society, in efforts to encourage the growing of film communities. Local Art Council doesn't cover all of the film communities and tends to giving attention only for their members. All stakeholders in the development of indie films are not synergy which then becomes counterproductive to the existence of indies movie community. To address this gap, a discussion forum is needed to find the best solution to resolve the issue of independent filmmaking in the local region.

\section{References}

1. Baksin, "Peranan Perkembangan Film Indie Terhadap Bangkitnya Film Nasional”, Jurnal Mediator, Vol 3(1) (2002).

2. Denzin, Norman K. and Yvonne S. Lincoln (eds), Handbook of Qualitative Research, terj. Dariyatno, Pustaka Pelajar, Jogjakarta (2009).

3. J. Storey, Culture Theory and Populer Culture, Prentice Hall, London (2001).

4. S. K. Arthur, "Sound of Praise: Reflexive Ethnopedagogy and Two Gospel Choirs in Tallahassee, Florida", Thesis, Florida State University, Florida (2004).

5. Ardial, Paradigma dan Model Penelitian Komunikasi, Bumi Aksara, Jakarta, (2014).

6. N. Irawan, "Film dan Teknologi”, Majalah Film No 173/14 (1993).

7. Nugroho, Garin \& Dyna Herlina S, Krisis dan Paradoks Film Indonesia, Kompas Media Nusantara, Jakarta (2015). 
8. Sasono, Eric et.al, Menjegal Film Indonesia, Pemetaan Ekonomi Politik Industri Film Indonesia, Perkumpulan Rumah Film dan Yayasan Tifa, Jakarta (2011).

9. Sosialisasi UU No 23 Tahun 2014 Tentang Pemerintah
Daerah : Pembagian Urusan Pemerintahan Bidang Kebudayaan, Direktorat Urusan pemerintahan Daerah II Ditjen Otonomi Daerah Kementerian Dalam Negeri, Jakarta (2015).

10. UU Perfilman Tahun 2008 